\title{
Robert Hooke's Scientific Library: Books from Duck Lane and Moorfields
}

\section{LEONA ROSTENBERG}

Ever on the prowl for books, the great scientist and book collector Robert Hooke (1635-1703) availed himself not only of those scientific texts sold by the successful dealers John Martyn of the Bell, Moses Pitt of the Angel, and Robert Scott of the Princess Arms but also those stocked by the lesser-known dealers of Duck Lane, Moorfields, Fish Street Hill, and elsewhere. As surveyor to the city of London after the Fire of September 1666, Hooke of necessity wandered through devastated areas, becoming equally familiar with Duck Lane near Aldersgate and Smithfield, and Moorfields close to Moor Gate and Bethlehem Hospital, which he rebuilt.

In his analysis of the seventeenth-century English book trade, John Dunton remarks: "It would be tedious and unconscionable to go through all Cheapside, Paul's Churchyard, Little Britain and Duck Lane to describe every Man, Woman, and Sucking-child, Bookseller, Auctioneer, Stitcher, Hawker, \&." A visitor to Duck Lane, the diarist Samuel Pepys refers to his "passing through the booksellers." Neither Hooke nor Pepys specifies by name a single dealer in this concentrated warren of books and book people. Their journals afford tantalizing clues, alluding "To Duck Lane at first shop . . . at second shop ... at third shop." The impression is given of small shops or stalls adjacent to each other, their wares jumbled together, some displayed in the open in crates or on rickety shelves. It is only through the imprints of these denizens of Duck Lane and Moorfields that their persons are reanimated-their anonymity shed-their proprietorship of the Crown, the Black Raven, the Bible, the Anchor, the Golden Bell reestablished. 1

1 John Dunton, The Life and Errors of John Dunton, Citizen of London (Westminster, 1818), I, 236; The Diary of Samuel Pepys, ed. H. B. Wheatley (London, 1928), VII, 378; The Diary of Robert Hooke .. 1672-1680, ed. H. W. Hobinson and Walter Adams (London, 1935), 199. 
From a study of an approximate 19 book dealers active in Duck Lane during the Restoration, it becomes apparent that the majority had met some adversity and had sought this less stylish area in which to pursue their profession. Some few beginners, once successful, deserted the district for a more distinguished address.

Although Dunton reiterates the honesty and good character of the Duck Lane dealers, he recalls their misfortunes in business and their general hard luck. Thomas Axe of the Blue Ball, known as "Honest Tom," had met with losses. "No man is more contented with his little, and so patient under any disappointment: but, notwithstanding his losses in trade, I believe Mr. Axe will get money enough." A little-known bookseller, Frank Hubbald, had "been unfortunate." Nonetheless his "courage and wisdom carried him with unwearied course through both Hemispheres of Prosperity and Adversity." Comparing the dealer Thomas Yates with himself, Dunton remarked that he had also suffered losses but "was still as honest as ever." William Whitwood was dubbed by Dunton "a rolling printer." He may have earned this sobriquet either because he dealt in engravings or because of his many moves in Duck Lane from the Swan to the Golden Lion, the Golden Bell to the Golden Dragon next door to the Crown Tavern. ${ }^{2}$

Others had sustained losses from the Fire which had swept through the booksellers' quarters in Saint Paul's Churchyard. Joshua Coniers, originally of Long Walk near Christ Church, had set up at the Black Raven, Duck Lane, while his colleague Samuel Thompson of Bishops Head, friend and bookseller to the Royal Society academicians, confessed that he had lost much in the wake of the Fire. William Thackeray of the Old Bailey had relocated at the Sugar Loaf, Duck Lane. ${ }^{3}$

The successful auctioneer Edward Millington, described by Dunton as one "of quick wit and a wonderful fluency of speech," abandoned Duck Lane, moving to Little Britain and later to Cambridge. Thomas Sawbridge, publisher and bookseller, left his old area for the Flower de Luce, Little Britain. ${ }^{4}$

The majority of the Duck Lane coterie were booksellers who lacked sufficient capital to engage in publishing. A few were tangential to the trade. Anderson, a weaver, together with the almanac maker, Thomas Streete, sold some of the works of the mathematician

2 Dunton, op. cit., I, 258, 229, 217, 292.

3 Henry R. Plomer, A Dictionary of the Booksellers Who Were at Work in England... from 1641 to 1667 (London, 1907), 51, 179, 176.

4 Dunton, op. cit., I, 235-236; Plomer, op. cit., 263. 
William Oughtred. Thomas Axe of the Blue Ball was binder, book+ seller, globe dealer, and auctioneer. ${ }^{5}$

Much of the Duck Lane stock comprised foreign and early English scientific texts. It is quite likely that many of these books were at the time in little demand and had been bought up quite reasonably at auction or in lots from established dealers in Saint Paul's Churchyard who were indifferent to their content. The small, little-known specialist in antiquarian science could scarcely vie with the dealer in the ever-popular modern firsts who offered his chic clientele the latest in Dryden, Cowley, Congreve, Waller, and other "in" authors.

To supplement his stock, the Duck Lane bookseller searched beyond London. Nicholas Boddington of the Golden Ball, for example, traveled "much in the country." Apparently his greatest asset, according to Dunton, was "his satisfaction to belong to a beautiful wife." The Stourbridge Fair lured several denizens of Duck Lane. Edward Millington of the Pelican conducted his first country sale at the Stourbridge Fair in 1684, selling a collection of English and foreign books. The Bibliotheca Sturbitchiana, copies of which were distributed gratis at all the Cambridge coffeehouses, included twenty-two hundred lots. The sale proved eminently successful and was repeated the following year. Among its visitors was William Shrowsbury of the Bible, Duck Lane, who, Dunton declared, was "a constant frequenter of the Stourbridge Fair."6

Samuel Pepys, an habitué of Duck Lane, appears to have been attracted to its crowded precincts not merely by bibliophilic but more so for amorous reasons. It is true that in February 1667/68 he acquired at one of the shops a copy of Athanasius Kircher's Musurgia for 35 shillings, "a book I am rightly glad of, expecting to find great satisfaction in it." Another visit resulted in his purchase of a copy of Montaigne's Essays in English. On the prowl for a copy of Mersenne's L'Harmonie Universelle, he searched the area. "It is not to be had, but I have given order for its being sent for." As compensation he purchased a copy of Descartes, "his little Treatise of $\mathrm{Mu}$ sique," in all likelihood the English translation published in London in 1653. Pepys's diary entry is of interest since it indicates that the

5 John Collins to Francis Vernon, n.d., in Stephen J. Rigaud, Correspondence of Scientific Men of the Seventeenth Century (Oxford, 1851), I, 115; Dunton, op. cit., I, 258 and Henry R. Plomer, A Dictionary of the Printers and Booksellers Who Were at Work in England . . from 1668 to 1725 (Oxford, 1922), 11.

6 Dunton, op. cit., I, 209, 235-236; John Lawler, Book Auctions in England in the Seventeenth Century (London, 1898), 70; Donald G. Wing, Short-Title Catalogue of Books Printed in England ... 1641-1700 (New York, 1945), B2857; Dunton, I, 221. 
Duck Lane dealer either enjoyed good relations with the larger London music firms or maintained contacts with the French trade which could provide him with a copy of Pepys's desideratum. ${ }^{7}$

Although Samuel Pepys, secretary to the Admiralty and bibliophile, purchased a copy of The Lives of the Saints of Jacobus de Voragine, his behavior on the day of purchase, April 10, 1668, was scarcely saintly, since either before or after the sale he tarried to kiss the bookseller's wife. This damsel-and not the folios or octavos of Duck Lane-continued to beckon Pepys thither: "passing through Duck Lane . . . only to get a sight of the pretty little woman I did salute the other night, and did in passing." Returning to the area, he acquired one work in Spanish and "there did I endeavor to see my pretty woman that I did baiser in las tenebras a little while depuis. And did find her sola in the book (shop) but had not la confidence par a aller a elle. But still another time." The "pretty woman" in question was the wife of Thomas Shrowsbury, proprietor of the Bible. Upon several later visits Pepys espied his "belle femme" but had "no opportunity para hazer con her." His passion, alas, was cooled when, upon a feigned business call to the Bible, October 23, 1668, he discovered his "belle femme" . . so "bigbelliled that elle is not worth seeing." There is no evidence that his future viewing in Duck Lane was confined to literature $!^{8}$

Unlike Pepys, the cantankerous Robert Hooke seldom if ever sought "les belles femmes," bigbellied or otherwise, within the shops and stalls of Duck Lane. Hooke's diary entries frequently refer to the purchase of books but offer only one clue to the identity of a bookseller-none to a wife. To specify exactly the names of the shops frequented by Hooke, it is necessary to eliminate those Duck Lane dealers who sold virtually no science. Hence the bibliophilic sleuth must stalk the area and investigate the activity and publications of Samuel Thompson, William Shrowsbury, Thomas Sawbridge, Joshua Coniers, and William Isles.

It is certain that Hooke was personally acquainted with Samuel Thompson of the Bishops Head, Duck Lane, who in 1661 published the scientist's An Attempt for the Explication of Phaenomena. Thompson, originally from Burfield, Shropshire, had arrived in Lon-

7 Pepys, op. cit., VIII, 312; Athanasius Kircher, Musurgia universalis (Rome, 1650), 2 vols.; Michel de Montaigne, Essayes (London, 1603, 1613, 1632); Marin Mersenne, L'Harmonie Universelle (Paris, 1636-1637); René Descartes, Excellent Compendium of Musick (London, 1653).

8 A. W. Pollard and G. R. Redgrave, A Short-Title Catalogue of Books Printed in England . . . 1475-1600 (London, 1946), 24873-24880, hereafter designated as STC; Pepys, op. cit., VII, 372, 378, 381; VIII, 65, 73, 121. 
don in 1634 and was apprenticed to Joyce Norton and Richard Whitaker, who freed him in January 1641. Nothing appears to be known of his activity during the following seven years. In 1648 he set up at the White Horse, Saint Paul's Churchyard. Suffering reverses in 1666 from the holocaust of the Fire, he moved to the Bishops Head, Duck Lane. According to the records of Richard Smyth, secondary of the Poultry Compter, "On Oct. 26, 1668 (at midnight) Sam. Thompson bookseller in Duck Lane obit, a good husband and industrious man in his profession."9

During his 20 years in business Thompson published an estimated 40 books, half of which are scientific in content. These include texts in physics, medicine, alchemy, and mathematics. With the establishment of the Royal Society, Thompson published, in addition to Hooke's treatise Of Phaenomena, John Wallis's Hobbius heautontimorumenos, Gilbert Clark's Tractatus de restitutione corporum, James Gregory's Optica promota, Gideon Harvey's Archelogia philosophica nova, and medical treatises of Everard Maynwaring. In 1668 Thompson crowned his literary production as one of the publishers of the first edition of Paradise Lost, the title page in fourth state. ${ }^{10}$

Before the Fire, Thompson had entertained high hopes of publishing the Latin version of the Observations on the Fixed Stars by the Persian astronomer Ulugh Beg, who had established an observatory at Samarkand in 1420. The findings of Ulugh Beg were considered to be the most accurate before those of Tycho Brahe. The manuscript of his Observations had been deposited at Oxford and aroused keen interest among the Royal Society astronomers. Thompson had apparently suggested a plan for publication which Wallis had considered not sufficiently comprehensive. In a letter of April 30, 1664, addressed by Wallis to Henry Oldenburg, secretary of the Royal Society, he remarked that "there may possibly be a mistake in $\mathrm{Mr}$. Thompson's apprehension, as thinking onely of a Latine translation, \& not of ye Persian to be printed with it." It is quite obvious that John Wallis, Savilian professor of mathematics at the University of Oxford, had little idea of the cost of exotic type or of the difficulty of procuring it. Actually Ulugh Beg's Tables were published in Persian the following year by the well-established Oxford dealer Richard

9 B. F. McKenzie, Stationers' Company Apprentices 1605-1640 (Charlottesville, Va., 1961), 404; Wing, op. cit., H2612; Plomer, op. cit., 179; The Obituary of Richard Smyth, Secondary of the Poultry Compter, ed. Sir Henry Ellis (London, 1849), 79.

10 Wing, op. cit., W811; C4450; G1912; H1053; M1501 and 2517; M2136.

[7] 
Davis, a copy of which was to be found in the Hooke Auction Catalogue. ${ }^{11}$

It was at Thompson's shop that the mathematician John Collins informed his fellow mathematician James Gregory that there he had read through a copy of Gregory's De quadratura circuli ex hyperbole. "He (Thompson) hath sent the other to Dr. Wallis." During a visit to Padua, Collins kept in touch with Thompson. ${ }^{12}$

As a bookseller Thompson not only imported foreign scientific texts but also kept abreast with current English scientific publications. Like several of his colleagues, he appears to have issued catalogs or lists of available material. During a visit to his premises, Oldenburg noted that the proprietor expected "within 4. or 8. dayes ye delivery of Kircher's Mundus subterraneus. I perceive ye price will amount to $50 \mathrm{sh}$. at least, and yet but one volume. I find also, by his Catalogue, yt yesame Kircher has publisht a Scrutinium Physico-medicum Pestis." Had not Pepys during a bibliophilic foray in Duck Lane found a copy of Kircher's Musurgia which had cost him 35 sh.? The texts of the Jesuit Athanasius Kircher had been printed in Amsterdam and Rome and were probably exported as a lot to a general London clearinghouse. In October 1665 Oldenburg informed Boyle that it was Thompson's wont "to acquaint [him] with the new Books, yt come abroad." The secretary of the Royal Society expressed some annoyance that Thompson had "neither then nor afore told [him] anything of Galilaeo's second Tome, but I shall ask him about it, God willing, ye next time I pass yt way." Oldenburg was no doubt alluding to Thomas Salusbury's version of Galileo's Mathematical Collections and Translations published by William Leybourn in 1665.13

During the plague in London in 1665 John Martyn of the Bell suspended publication of the Philosophical Transactions which during the autumn were taken over by Richard Davis of Oxford. Boyle suggested that copies be sent down from Oxford to Thompson, to which

11 John Wallis to Henry Oldenburg, April 30, 1664, in The Correspondence of Henry Oldenburg (Madison, Wis., 1966), II, no. 314, henceforth designated as Oldenburg, Correspondence; Wing, op. cit., U23; Bibliotheca Hookiana. Sive catalogus diversorum librorum insignium Dott. R. Hooke . . . sibi congessit (London, 1703), 299q(uarto), henceforth designated as $H C$.

12 Wing, op. cit., G1909, possibly Exercitationes geometricae (London, 1668); Collins to Gregory, n.d., in Rigaud, op cit., II, 172.

13 Oldenburg to Boyle, April 18, 1665, in Oldenburg, Correspondence, II, no. 412; Athanasius Kircher, Mundus subterraneus (Amsterdam, 1655) and Scrutinium (Rome, 1658); Wing, op. cit., S517; Oldenburg to Boyle, October 10, 1665, in Oldenburg, Correspondence, II, no. 430; Wing, S517. 
Oldenburg rejoined that in addition they be circulated among more central shops located "about ye Exchange."14

It was at the sign of the Bible, Duck Lane, that Samuel Pepys, secretary to the Admiralty, "did baiser" the proprietor's wife "in las tenebras." During this romantic interlude it is quite possible that the lady's spouse, William Shrowsbury, was scouting books in London, attending the Stourbridge Fair or even discussing the desiderata of his somewhat exacting customer Robert Hooke. Although the scientist does not specify a visit to the Bible, his purchases suggest that a goodly number may have been bought from Shrowsbury, the principal publisher of the writings of the jurist, philosopher, and scientist Sir Matthew Hale. The constant exchange of books among members of the London book trade is attested by Hooke's Diary entry of December 23, 1676: "Sent to Mr. Martin for Sir Ma. Hales book." Martyn was Hooke's preferred bookseller and had probably ordered copies of Hale's texts from Shrowsbury. In addition to the publications of Sir Matthew, Shrowsbury stocked various antiquarian scientific texts. ${ }^{15}$

Of the proprietor of the Bible, Dunton somewhat rhapsodically writes: "The morning of his life was clear and calm, and ever since his whole life has been a continued series of honesty; then no wonder he printed for Judge Hales. He merits the name of 'Universal Bookseller,' and is familiarly acquainted with all the Books that are extant in any Language. He keeps his Stock in excellent order, and will find any Book as ready as I can find a word in the Dictionary. He is a great Ornament to the Stationers Company, and may justly be called Venerable for his heavenly aspect wherein gravity and sweetness are all compounded." 16

From 1672 to 1688, William Shrowsbury was active at the Bible, Duck Lane, where he published an approximate 18 books, the majority of which represent the miscellaneous writings of Judge Hale. Shrowsbury's first publication, Sterometrie, or the Art of Practical Gauging, by J. Smith "Philo-Accomptant" selling for " $3 \mathrm{~s} .6 \mathrm{~d}$. bound" appeared in 1672. Hale's scientific texts include his Essay Touching the Gravitation or Non-gravitation, of Fluid Bodies, "bound 1 sh.," Difficiles Nugae or Observations Touching the Torricellian Experiments, "bound 1 sh.," Observations Touching the Principles of Natural Motion, and his most significant work, The Primitive Origination of

14 Boyle to Oldenburg, December 9, 1665, in Oldenburg. Correspondence, II, no. 469 ; Oldenburg to Boyle, December 19, 1665, in II, no. 473.

15 Hooke, op. cit., 264.

16 Dunton, op. cit., I, 221. 
Mankind. A balneological treatise, Spadacrene Dunelmensis, or a Short Treatise of an Antient Medicinal Fountain, or Vitrioline Spaw, near the City of Durham, "bound 1 sh.," bore the 1675 imprint of Shrowsbury, who seven years later issued A Tryal of Witches Held at the Assizes of Bury St. Edmunds. ${ }^{17}$

There is every indication that Shrowsbury stocked general as well as scientific books. Pepys found at the Bible not only his temporary inamorata but also a copy of Voragine's Golden Legend and upon occasion "did there look and buy some books." Hooke's Diary records at least six visits to Duck Lane, and there can be little doubt that he found much of interest at Shrowsbury's premises. On a buying venture of December 17, 1672, he refers to the purchase of "Descartes Epistles 6 sh., Leotauds Cyclomathia \& 3 sh., Dutch book 1 sh., and Fioravantys trades 8 d." He had obviously acquired the London 1653 edition of Descartes Epistolae. Pepys had earlier referred to his acquisition of "Descartes his little Treatise of Musique." Both works were apparently available at the Bible. Vincent Leotaud, Cyclomathia ... Libri III had been published at Lyons in 1633 and two English editions of different works of Leonard Fioravanti had appeared in London in 1652 and 1659.18

Hooke offers the bibliophilic detective one clue in his search for the identity of yet another Duck Lane dealer. On April 16, 1674, he writes: "Bought [books] next Blew Anchor in Duck Lane." Thomas Sawbridge was the proprietor of the shop next the coffeehouse, the Blue Anchor in Duck Lane. He published several scientific writings including a few of the draughtsman and mathematician, William Leybourn, a close friend of Hooke. Leybourn and Hooke certainly dropped in at Sawbridge's shop after a session with mutual friends at the Blue Anchor, which had an entrance in Duck Lane. ${ }^{19}$

Thomas Sawbridge, in all likelihood a member of the successful Sawbridge stationer family, began as publisher and bookseller at the Anchor, Duck Lane, in 1655 and continued for 37 years, during which time he issued and sold a variety of scientific texts. Among his successful sales were two editions of Leybourn's The Art of Dialling and his Cursus mathematicus. In addition, Sawbridge published two editions of Joseph Darling, The Carpenters Rule Made Easy,

17 Edward Arber, The Term Catalogues 1668-1709 (London, 1903), I, 118; Wing, op. cit., S4096; Arber, I, 134, Wing, H244; Arber, I, 171, Wing, H238; Arber, I, 267, Wing, H252; Wing, H258; Arber, I, 218, Wing, T2240; Arber, I, 484.

18 Pepys, op. cit., VIII, 61; Wing, D1130; Jean G. T. Graesse, Trésor de Livres Rares et Precieux (Milan, 1950), IV. 168; Wing, F953, F952.

19 Hooke, op. cit., 96; Dunton, op. cit., I, 21 I-212. 
"bound 2 sh.," Henry Coley, Clavis astrologiae elementa, two editions of Palladio, First Book of Architecture, and two editions of Hodder's Arithmetick at 1 s. 4 d. each, and other miscellaneous texts. Obviously Sawbridge's varied stock appealed to the multifaceted interests of Robert Hooke. In his specific reference to "the [shop] next Blew Anchor" Hooke cites the purchase of "Clusius variorum plantarum historia $6 \mathrm{~d}$. ejusdem exoticarum libri $10 \mathrm{~s}$. cum observationibus Bellonii 4 s. Cardanus de proportionibus \& Algebra 2 s. Paid him by Harry." Hooke had acquired the highly prized botanical treatise of Charles L'Ecluse, his Rariorum plantarum historia published by Plantin at Antwerp in 1601 and the author's Exoticarum libri of 1605, as well as the mathematical treatises of the ever-popular Jerome Cardan. Apparently Hooke had sent his assistant Harry (Hunt), also operator of experiments at the meetings of the Royal Society, to settle the account. 20

Hooke's Duck Lane purchase of July 23, 1675 is described as "Albert Durers works for 4 sh." He may have obtained any one of the great artist's technical treatises or even a collection of prints. There is also the possibility that he purchased the recently London-published Albert Durer Revived; or, a Book of Drawing, Limning, Washing or Colouring of Maps and Prints, a work most useful to Hooke, the map "pricker" and artist. The auction catalog of Hooke's library attests, however, to a copy of Dürer's "De symetria," actually his singularly important treatise De Simmetria partium in rectis formis humanorum corporum libri, Nuremberg, 1528, which at the disposal of the scientist's collection in 1703 fetched one pound. ${ }^{21}$

A sizable purchase of 13 books is mentioned by Hooke on August $24,1675-“ a l l$ in $8^{\circ} 2 \mathrm{~s} .6$ d." The collector indeed knew a bargain! These titles could have been obtained either from Sawbridge or Shrowsbury. The lot includes, among others, the Historia vitae et mortis and the Historia de ventis of Sir Francis Bacon, published in London in 1623 and 1671 respectively. Other titles mentioned are "Digges, Calendar, Burning London, Hood of the Sector, Wright of the Sphere, Finaeus de Horologii, Gellibrand of the Variation of the Needle, Shakerley against Urania practica, De la Main, Circles of proportion, Sir Christ. Heydon Astrology, Street \& Childreys Almanacks for 1653." The majority of these titles are of English origin.

20 Ibid.; Wing, L100; L1911; D261, D262, Arber, op. cit., I, 18; Wing, C5099; P206, P207; H2287, H2288; Graesse, op. cit., II, 204; II, 45; for Hunt, see Hooke, op. cit., passim.

21 Hooke, op. cit., 170; Leona Rostenberg, English Publishers in the Graphic Arts 1599-1700 (New York, 1963), 76; for Dürer, "De Symetria," see Universal Catalogue of Books on Art (London, 1890), I, 457, HC 17, App. Libri Misc. 4to. 
Leonard Digges, Prognostication ... Contayning Rules to Judge the Weather appeared in several editions from 1578 to 1605 ; London's Flames was a recent publication, 1667, detailing the ravages of the great Fire. Thomas Hood, The Making and Use of the Sector was published by Windet in 1595, and The Description and Use of the Sphaere of Edward Wright appeared in 1598 and 1631. Oronce Fine, De solaribus horologiis \& quadrantibus libri quatuor, an important continental text by the celebrated French scientist, issued in 1560, is listed exactly in the Hooke auction catalogue. Gellibrand, Discourse Mathematical of the Variation of the Magneticall Needle and Shakerley, Anatomy of Urania Practica were printed in London in 1635 and 1649. Grammalogia or the Mathematical Ring-sold in a lot of four books at the Hooke auction sale-was the work of the English mathematician Richard Delamain, while Christopher Heydon's Defence of Judiciall Astrology appeared at Cambridge in 1606.22

In late December 1675 Hooke refers to a book-hunting jaunt in Duck Lane "at the first shop west." The character of his purchases suggests that he had again visited Shrowsbury's premises, since, among other items, he acquired "Harriots Algebra 1 s. 6 d., Snellius triangulis 6 d., Schooten Sines Secantes Tangentes, R.B. Arithmetick 6 d., Shakerley's Tables 2 sh. Against Galilaeo 2 tracts 6 d." Of these items three had been published in England prior to the Restoration and may have been picked up by Shrowsbury at the Stourbridge Fair. ${ }^{23}$

A book-buying trip of December 11, 1675, reanimates the bookish aspects of Duck Lane. Here Hooke browsed in three book stores: "the first shop, the second shop, the third shop." The scholar-detective is frustrated by the anonymity of ownership; the collector is titillated by the image of a vast sea of books! The "first shop" may have been that of William Isles, publisher of a single work which is listed in the Hooke Auction Catalogue: Lucas Jacobsen Debes, Faeroae et Feroae reserata (London 1676). A Description and History of the Faroes, islands off the Danish coast, had been translated into English by the Scotsman John Sterpin, who had rendered a most faulty Latin version of a part of the Philosophical Transactions. Published by Isles in 1676, the work sold at 2 s. $6 \mathrm{~d}$. Hooke also states that he had

22 Hooke, op. cit., 176; STC, 1156; Wing, op. cit., B306, HC 190q also HC EB12mo; STC, 6860, 6861; Wing, L2928; STC, 13695; STC, 26021; Short-Title Catalogue of Books Printed in France . . from 1470 to 1660 Now in the British Museum (London, 1924), 166; STC, 11712; Wing, S2911; STC, 6542; HC26EB; STC, 13266; Wing, A2406.

23 Hooke, op. cit., 183; STC, 12784; Graesse, op. cit., VI, 426; Alphonse Willems, Les Elzevir (Nieuwkoop, 1962), 811; Wing, op. cit., B157; S2912. 
purchased at the same shop a first edition of Oughtred. A letter of John Collins to Francis Vernon refers to one Isles a bookseller in Duck (Lane) who had "bought some of Oughtred's books." In addition Hooke selected a "written map, a copy of the Optics of the Arabic scientist Alhazen and the Logarithms of Napier."24

His bibliophilic passion still running high and his purse still fat, Hooke proceeded to the "second shop," which might have been the Black Raven owned by Joshua Coniers, a post-Fire resident. The few books published by Coniers are of a miscellaneous scientific nature: Meteorologia by William Cock "Philomath," A Guide to the Young Gager by Simon Jones, Thomas Streete and Robert Anderson, as well as several works by the astrologer Henry Coley. Hooke appears to have been quite discriminating during his visit, selecting only one work: Thomas Digges, Alae seu scalae mathematicae (London 1573). The browser completed his day's rounds at the "third shop," possibly that of William Whitwood of the Golden Bell, who had been hailed by Dunton as "a rolling printer." Whitwood had begun publishing at another Duck Lane premise, the Golden Lion, in 1669, when he issued Two Discourses: The First Concerning the Different Wits of Men. The Second, the Mysteries of Vintners ... "Delivered to the Royal Society. Price bound 2 sh." Other Whitwood imprints include books on travel, medicine, archeology, and miscellaneous subjects. It was at this, the "third shop," that Hooke selected a variety of texts: Pellison, Relation contenant l lhistoire de l'Academie François; Jacques Billy, Nova geometria; Bartholomaeus Pitiscus, Trigonometria and one of the many works of the Italian scientist Ulysses Aldrovandus. ${ }^{25}$

If Hooke's bibliophilic thirst had not been sufficiently allayed by Duck Lane attractions, he could easily have slipped through Aldersgate to Moorfields near Moor Gate and London Wall. This somewhat rural area, drained in 1527, had during the early reign of James I been converted into a partial recreation center with pleasant attractive walks. Here the militia paraded "with pykes and bowes in bluw clokes garded with red." Studded with windmills, small shops, and stalls, ale- and coffeehouses, it appealed to Hooke, Pepys, fellow academicians, and the general public for relaxation on a pleasant day. Here Pepys enjoyed the wrestling matches between north and west

24 Hooke, op. cit., 392, HC47EB12mo; Wing, D511; Arber, op. cit., I, 217; Collins to Vernon, n.d., in Rigaud, op. cit., I, 151; Short-Title Catalogue of Books Printed in the German-Speaking Countries... from 1455 to 1600 Now in the British Museum (London, 1962), 383; HC270f; STC, 18351.

25 Arber, op. cit., I, 55, 26; Wing, C5098-C5099; STC, 6871; Arber, I, 14, 58, $59,245,156$; Graesse, op. cit., V, 190; I, 426; V, 306; for various works of Aldrovandus, see Graesse, I, 65. 
countrymen; witnessed several times a merry performance of Ponchinello; bought a set of compasses at the shop of one of the instrument makers; sought out a pretty damsel or discussed the snow and drabness of Russia with his friend Mr. Pargiter. During the Plague and the Fire refugees here sought haven from the spreading infection and the destruction of the city. "I went forth and walked towards Moorfields to see . . . whether I could see any dead corps going to the grave," wrote Pepys in August 1665, and a little over a year later during the height of the Fire he discovered the area "full of ... poor wretches carrying their goods there, and everybody keeping their goods together by themselves." 26

It was at Moorfields in 1676 that Robert Hooke, city surveyor and architect, rebuilt Bethlehem Hospital, a structure which in Evelyn's opinion "was magnificently built and most sweetely placed in Morefeilds since the dreadful fire of Lond." The area was fast becoming a patchwork of haphazard new buildings, including shops and stalls. During his numerous visits there Hooke "viewed Lands at Cripplegate and Bunhill Place"; ate bacon at the Windmill and imbibed ale at the Sun, Moor Gate. Moorfields lured the scientist professionally and bibliophilically. Like Duck Lane, this less affluent area attracted both the younger bookseller and his older colleague who had met with adversity. Their stocks, similar to those of the Duck Lane professional, comprised largely antiquarian texts appealing little to the stylish collector interested in new English or French novels, smart plays, and sumptuous bindings. ${ }^{27}$

The bookshops and stalls of Moorfields, probably less numerous than those of Duck Lane, appear to have had greater interest for Hooke. His later diaries, from 1668 to 1693 , indicate frequent visits and often an unsuccessful book "bag" which is tersely indicated "MF"." Like the publishers and booksellers of Duck Lane, their Moorfields colleagues remain for the most part anonymous. With the exception of Hooke's specific reference to the art specialist Robert Pricke and the premises of the Golden Fleece, the remaining stationers of Moorfields are reanimated only through the meager publications and the titles acquired by Hooke. In the latter case, association of specific books with specific dealers must be conjectural.

The somewhat careless attitude of the Moorfields dealer toward his jumble of books is suggested by two terse entries of March 21 and 23, 1692/93 in Hooke's later diary. "In MF I saw neer 100 of Mr. Boyles

26 R. J. Mitchell, A History of London Life (London, 1958), 120; Pepys, op. cit., I, 52; II, 56; V, 384; IV, 228; V, 57, 401.

27 The Diary of John Evelyn, ed. E. S. DeBeer (London, 1959), 648. 
high Dutch Chymicall books ly exposed in Moorfeilds on the railes. Till 11/2 in MF saw many of Mr. Boyles German chemicall books." One can only deduce that the books which had once belonged to the greatest of English chemists lay exposed on shelves or crates in front of a stall or shop subject to the moods of weather and customer. A nonconformist divine, possibly Zachary Merrill, had visited Boyle's library-still intact-approximately a year earlier. He declared it contained " 330 fol. 801 qtos. 244 oct. and 12. most of ym well bound. They may be had for 3 or $400 \&$ (tho' worth 1000) because they must not be sold by Auction." The collection on display was to have been sold at the house of Boyle's sister, the late Lady Ranelagh. Negotiations fell through and the books were shipped to Moorfields, where individual items were sold. The remainder were dispatched to Tom's coffeehouse where, together with the library of the arms painter Silvanus Morgan, they were put up for public auction. Hooke records on March 28, 1693, that he "read a Catal. of Morgans and Boyles books at Toms." It is almost impossible today to recognize a book from Boyle's library, since his collection had been bundled together anonymously with that of Morgan and the public was offered mixed lots indifferent to the provenance. It has been the good fortune of Madeleine B. Stern and this author to have owned a book once in Boyle's library: Louis de Montpersan, La Politique des Jesuits (London 1658). An inscription on the flyleaf reads "Ex bibliotheca illustrissimi, doctissimique viri Domini Roberti Boyle ultimo die anno 1691 defuncti." The buyer had purchased it either from the "railes" at Moorfields or at the Boyle and Morgan auction held at Tom's coffeehouse April 5, 1693. Perhaps wishing posterity to be mindful of its distinguished provenance, he recorded it on the flyleaf. ${ }^{28}$

At least 20 years prior to the unfortunate dispersal of the Boyle library, Hooke had begun his forays into the Moorfields stocks. His myriad interests are reflected in his purchases of texts in mathematics, technology, surveying, chemistry, astronomy and astrology, art and architecture, voyages and travel, and the wonders of the New World.

In June 1672 he acquired a copy of Hugh Plat, Jewel House of Art and Nature, followed by the purchase of "Bulwar's Muscles." The latter was bought at the Golden Fleece, whose proprietor Richard South-

28 Hooke's numerous visits to Moorfields for book purchases are listed in his Diaries, November 1688 to March 1690 and December 1692 to 8 August 1693. For both Diaries, see R. T. Gunter, Early Science in Oxford (Oxford, 1930), X; Hooke, Diary 1692 to August 1693, 223, 224, 228; for the fate of Boyle's library, see John F. Fulton, A Bibliography of the Honourable Robert Boyle, Fellow of the Royal Society (Oxford, 1961), 2nd ed., iv-vi. 
by was a fairly inactive bookman. Credit is given to him by Dunton for having a "Wife of a good Fortune." Southby had apparently met with business adversity and sought the cheaper rental of a Moorfields shop. According to Dunton, he had run a coffeehouse, since "it was not his luck to get estate by Authors; and I wish he may get it by Coffee." Perhaps Hooke sipped a strong brew while flipping through the pages of Bulwer's treatise, Pathomyotomia, or a Dissection of the Significative Muscles of the Affections of the Minde. ${ }^{29}$

Tangential to the art of the book was the development of technique in gilding and dyeing, both of which were practiced in Moorfields. In June 1652 Evelyn had observed "the manner of chambletting silk \& Grogans at one Monsieur La Dorees in Moorfields." Some 20 years later his fellow academician Robert Hooke spent some time in the area with Philipp Barret, a quasi-stationer, who experimented in the manufacture of ink, gilding, and dyeing. Hooke refers to Barret's "new Printer's Black and varnishing" which he considered "very fine." With Barret on March 11, 1673/74, he made a trial of "gilding flowerd shift which succeeded." Barret apparently carried a small stock of graphics, since Hooke refers to the purchase of a map from him. ${ }^{30}$

Robert Pricke's association with the book trade was far closer than Barret's. Art and print specialist, Pricke was established at the Golden Lion, corner of New Cheapside next Bethlehem in Moorfields. Obviously Hooke could easily drop in at Pricke's shop before or after work on the construction of Bethlehem Hospital. Here he acquired pencils for his drafting, books on perspective, art and architecture, and interior decorating. ${ }^{31}$

Pricke's interest in the translating and publishing of important French architectural treatises was intensified by the ravages of the recent great Fire of September 1666 which had destroyed much of London. The Fire had consumed 13,200 houses, 87 parish churches, the Royal Exchange, and 52 company halls. A metropolis was to be rebuilt. A hastily issued proclamation of September 13, 1666, declared that "the city should rise resplendent making it rather appear to the world as purged with fire ... to a wonderful beauty and comeliness than consumed by it." Pricke's publications were timely and essential for designer, architect, and builder. ${ }^{32}$

Fluent in French, Pricke himself had translated several notable

29 Wing, op. cit., P2390, P2391; B5468; Dunton, op. cit., I, 235.

30 Evelyn, op. cit., 320; Hooke, op. cit., 56, 379.

31 For Pricke, see Rostenberg, op. cit., 55-60; Hooke, op. cit., 184.

32 Rostenberg, op. cit., 57. 
architectural treatises: A New Treatise of Architecture according to Vitruvius from the French of Julien Mauclerc; Jean Barbet, A Book of Architecture "adorned with 150 copper plates." Other Pricke publications certainly attracted Hooke, the surveyor and draughtsman: Ornaments of Architecture, described as a manual for "Painters, carvers, Stone-Cutters and Plaisterers" sold at 5 sh.; Henry Coggeshall, Timber Measure and The Store House of Architecture. ${ }^{33}$

Pricke's architectural list included a work of considerable influence. In 1669 he translated from the French and published A Nevv Book of Architecture wherein Is Represented Fourty Figures of Gates and Arches Triumphant originally compiled by Alessandro Francini, the Florentine engineer of Louis XIV. A copy is listed in the Hooke Auction Catalogue of 1703. It may be assumed that many of the architectural studies owned by Hooke had been obtained from Pricke: copies of the works of Vitruvius, Alberti, Boeckler, and others. ${ }^{34}$

Among the Pricke imprints is his 1670 translation of Pierre Le Muet, The Art of Fair Building. It is interesting to note that Hooke, a fairly frequent visitor to the Pricke establishment at the Golden Lion, did not at this time buy the English version but preferred to acquire the first French edition, Paris, 1623. It was not until 1674 that he obtained a copy of the Pricke translation along with Philip Vingboon, Gronden ... der voornaamste Gebowen, Amsterdam, 1675, doubtless a continental import. According to his diary he had purchased both architectural treatises "from Thomsons, Bedford Street." Richard Thompson was a specialist in objets d'art and mezzotints. According to Hooke "a curious inlay'd table" had attracted him to the shop. ${ }^{35}$

During a visit to Pricke, October 7, 1675, Hooke remarked that there he had seen "Palladio Englisht." It may be assumed that Hooke had acquired the English version from its translator, his friend, the book and map dealer Godfrey Richards, who published the book in 1663. Richards declared he had been inspired to undertake the translation and publication of Palladio's treatise because "of the scarcity of Books of Architecture in English and the zeal which he discovered our Ingenious Artists have to entertaine anything of that subject."36

33 Wing, op. cit., M1326; Arber, op. cit., I, 19; 30.36; Wing, D2411, D2412, Arber, I, 173; Wing, C4891.

34 Wing, op. cit., F2056, Arber, op. cit., I, 19, HC 113EB; Vitruvius, Architecture (Amsterdam, 1681), HC $443^{\circ}$ (Hooke owned several editions of Vitruvius); Leon-Battista Alberti, L'Architettura (Venice, 1565), HC 538q; Boeckler, Architetura, HC 291f.

35 Wing, op. cit., L1047, Arber, op. cit., I, 19; HC7For. fo.; HC2For. fo.; Hooke, op. cit., 129; for Thompson, see Rostenberg, op. cit., 50-53; Hooke, 232.

36 Hooke, op. cit., 185, HC137EB; for Richards, see Rostenberg, op. cit., 53-55; Hooke owned several editions of Palladio: HC137EB, 288fo., $289 \mathrm{fo}$. 
Hooke's diary entries shed light not only upon his personal taste but also upon the interchange of books among dealers. Although he was a close friend of Pricke and a faithful visitor to the shop, he purchased Pricke's English version of Le Muet's Art of Fair Building from Thompson. Again he had seen a copy of "Palladio Englisht at Prickes" but bought a copy from the translator Richards.

As a surveyor of a metropolis to be rebuilt, Hooke required technical studies which he hunted in the Moorfields shops and stalls. From the publisher-bookseller William Birch of New Cheapside he, in all likelihood, acquired his copy of Michael Dary, Miscellanies, sold by Birch and associates in 1669 . He may also have obtained at Birch's premises, in addition to William Leybourn, Panorganon or a Universal Instrument, texts serving his many interests: A True and Faithful Account of the Four Chiefest Plantations by Samuel Clarke of Grendon-Underwood, Bucks., A Description of the Seventeen Provinces, and for diversion a copy of John Crowne's Juliana. ${ }^{37}$

There can be little doubt that Hooke found books and technical accessories at the shop of Walter Hayes of the Cross Daggers, Moorfields. Available to him were copies of Leybourn's Use of the Semicircle, Walgrave's Decimal Arithmetick, Twysden, Use of the General Planisphere, and Seth Partridge, The Description and Use of an Instrument called the Double Scale. ${ }^{38}$

Hooke's quest for technological texts resulted in his acquisition of two extremely important works: William Ames, Philosophemata technometria, 1646, at $5 \mathrm{~d}$. and the handsomely illustrated Spanish edition of Jacques Beasson, Teatros de los Instrumentos, Leon, 1602. ${ }^{39}$

A prestigious mathematician, Hooke prowled Moorfields for books in the field, acquiring Charles de Bouelles, Geometrie pratique, 1547, at 31/2 d., Michael Constantius Psellus, Calculus, 1558, at $\frac{1}{2}$ d., and the contemporary text of Johann Heinrich Rahn, Introduction to Algebra. Interested in marine science and meteorology, he acquired a copy of A. Van Berlicom, Treatise on Longitude, and the English edition of Libert Froidmont, Meteorologica, at $2 \mathrm{~d}$. Hooke was an excellent astronomer and a dabbler in astrology. Hence his Moorfields jaunts produced a copy of Welper, Epitome astronomiae and "some astrology books." Throughout his life he evinced some curiosity about the occult and hence it is not surprising that he paid $14 \mathrm{~d}$. for a copy of

37 Wing, op. cit., D278; L1928; C4558, C4507, C7393.

38 Ibid., L1935; Arber, op. cit., I, 301; II, 146, Wing, P631.

39 Hooke, Diary, November 1688 to March 1690, 90, 152; HC286fo; Wing, op. cit., A3002. 
Cardan, De subtilitate and $1 \mathrm{sh}$. for De Justificatione daemonum of Pico della Mirandola. ${ }^{40}$

A diary entry of March 22, 1692/93, states that Hooke paid $6 \mathrm{~d}$. for "2 Dutch chymick books." In all likelihood he had acquired them from the library of his late esteemed friend Robert Boyle-those books exposed on the railes of Moorfields. ${ }^{41}$

An incurable hypochondriac subject to "guidiness and ill stomack," Hooke constantly dosed himself with spirits of hartshorn and senna, availed himself of cupping and clysters of Venice treacle. There is little wonder that medical books form the largest section of his collection nor that he searched Moorfields for wondrous cures and remedies. Here he paid $2 \mathrm{~d}$. for Cardan's Ars curandi parva-little for little -and Juan Fragoso, Discursos de las cosas aromaticas de la India Orientale. If the Eastern aromatic spirits of Señor Fragoso failed to allay Robert Hooke's chronic catarrh, the botanical texts of William Hughes surely afforded some remote fragrance. In April 1663 he picked up copies of Hughes, Compleat Vineyard and Flower Garden. ${ }^{42}$

Hooke's bibliophilic migrations seldom took him beyond his familiar haunts. Yet his great intellectual curiosity bore him beyond deepest sea and highest peak. His mind inquired into the remote, the hazardous, the unknown. He eagerly searched for Americana, and at the premises of John Martyn and Moses Pitt he obtained volumes detailing the vastness and untracked depths of the new world. In Moorfields he bought copies of Sir Ferdinand Gorges, America Painted to Life and The Reformed Virginian Silkworm by his fellow academician Samuel Hartlib. ${ }^{43}$

Beyond the precincts of Duck Lane and Moorfields Hooke sought out the vendors of material scientifica. His Diary sheds new light on ephemeral members of the book and instrument trade who eked out an existence by an incidental sale, living precariously on the profes-

40 Hooke, Diary, November 1688 to March 1690, 72, 73; Diary, December 1692 to August 1693, 224, 246; Diary, November 1688 to March 1690, 75, 149, 143; Diary, December 1692 to August 1693, 211; STC of French Books, 78; 367; Wing, K136; Graesse, op. cit., VII, 254; Wing, L2235, 2236; Welper was probably printed at Strasbourg, 1619; STC of French Books, 91; Short-Title Catalogue of Books Printed in Italy . . . from 1465 to 1600 Now in the British Museum (London, 1958), 515, HC7580.

41 Hooke, Diary, December 1692 to August 1693, 224.

42 Hooke, Diary, November 1688 to March 1690, 156. Cardan is, possibly, the Latin edition of STC of Italian Books, 149; Henry Thomas, Books Printed in Spain . . . before 1601 Now in the British Museum (London, 1921), 36; Hooke, Diary, December 1692 to Augtust 1693, 299; Wing, H3333, H3336.

43 Hooke, Diary, December 1692 to August 1693, 219; Wing, G1300-1302; H1000. 
sional fringe. "Bought of Moran Street's Sphere 2 sh., at Lyes paid $1 \mathbf{s}$. for Speidell's Logarithmotechnica." From the bookseller and instrument maker Henry Win or Wynne, Hooke purchased several antiquarian texts: an edition of Euclid edited by John Dee, Andreas Schoner, Gnomonica and Henry Briggs, Logarithmicall Arithmeticke at $5 \mathrm{sh}$. Win was established at Chancery Lane where, according to the author Henry Bond, he had experimented with the magnetical inclinatory needle. Hooke stated that he had seen "Dipping Needle at Wins" and had bade him send weather glasses to Lord Ranalagh. 44

Hooke was busy taking views in the vicinity of Fish Street Hill. There he had the opportunity to view the stock of the widow of Dixy Page, specialist in books on surveying and marine science. Dixy Page had begun business as publisher and bookseller at the Anchor and Marriner in East Smithfield. There is evidence that among Hooke's earliest purchases from him was a copy of Reginald Scot, Discovery of Witchcraft. Dixy Page died before 1675 and his widow moved to Fish Street Hill. Although her firm was small, she provided Hooke with essential texts in her late husband's specialties. Here he obtained works by the gauger John Newton, Edward Wright, The Seaman's Tutor, and in September 1675 a sea grammar and sea dictionary. ${ }^{45}$

In his great bibliophilic ardor Hooke searched scientific volumes at the premises of other dealers, some large, some small. He patronized Robert Littlebury, Walter Kettilby, William Starr, Richard Mount, and William Fisher. His Diary attests to his assorted purchases. Yet there is little doubt that he savored most keenly those jaunts to Duck Lane and Moorfields with their jumble of shops, their antiquarian books, their dealers recounting past glories, Micawbers anticipating a brighter morrow. Relishing the passion of the chase, Hooke wandered into the Golden Bell, the Blue Ball, the Crown Tavern, the Bishops Head, the Golden Fleece, the Bible and scouring Moorfields found "on the railes ... Mr Boyles high Dutch Chymicall books," of which he purchased two. There he took his sights, surveyed Cripplegate and Bunhill; built Bethlehem Hospital; visited his friend Robert Pricke at the Golden Lion. At the Windmill he downed a beaker of ale with a rasher of bacon, later strolling along a neatly laid-out walk with his friend, the astronomer Edmund Halley, discussing the stars

44 Hooke, op. cit., 106; Hooke, Diary, December 1692 to August 1693, 107; Wing, S4912; Arber, op. cit., I, 305; Hooke, op. cit., 147, 324, 153, 456; Euclid, STC, 10560; Schoner, STC of German Books, 792; Briggs, STC, 3740.

45 Plomer, op. cit., 1641 to 1667, 143; Wing, S945; HC59EB; Hooke, op. cit., 181; HC301EB; Wing, S6096; Hooke, op. cit. 181. 
and the planets and perhaps the new edition of Dr. John Wilkins' A Discovery of a New World in the Moon. The congeries of minor publishers and booksellers clustered in Duck Lane and Moorfields played as interesting a role in the development of Robert Hooke's library as the greater stationers in Saint Paul's Churchyard, Westminster, and the Strand! 


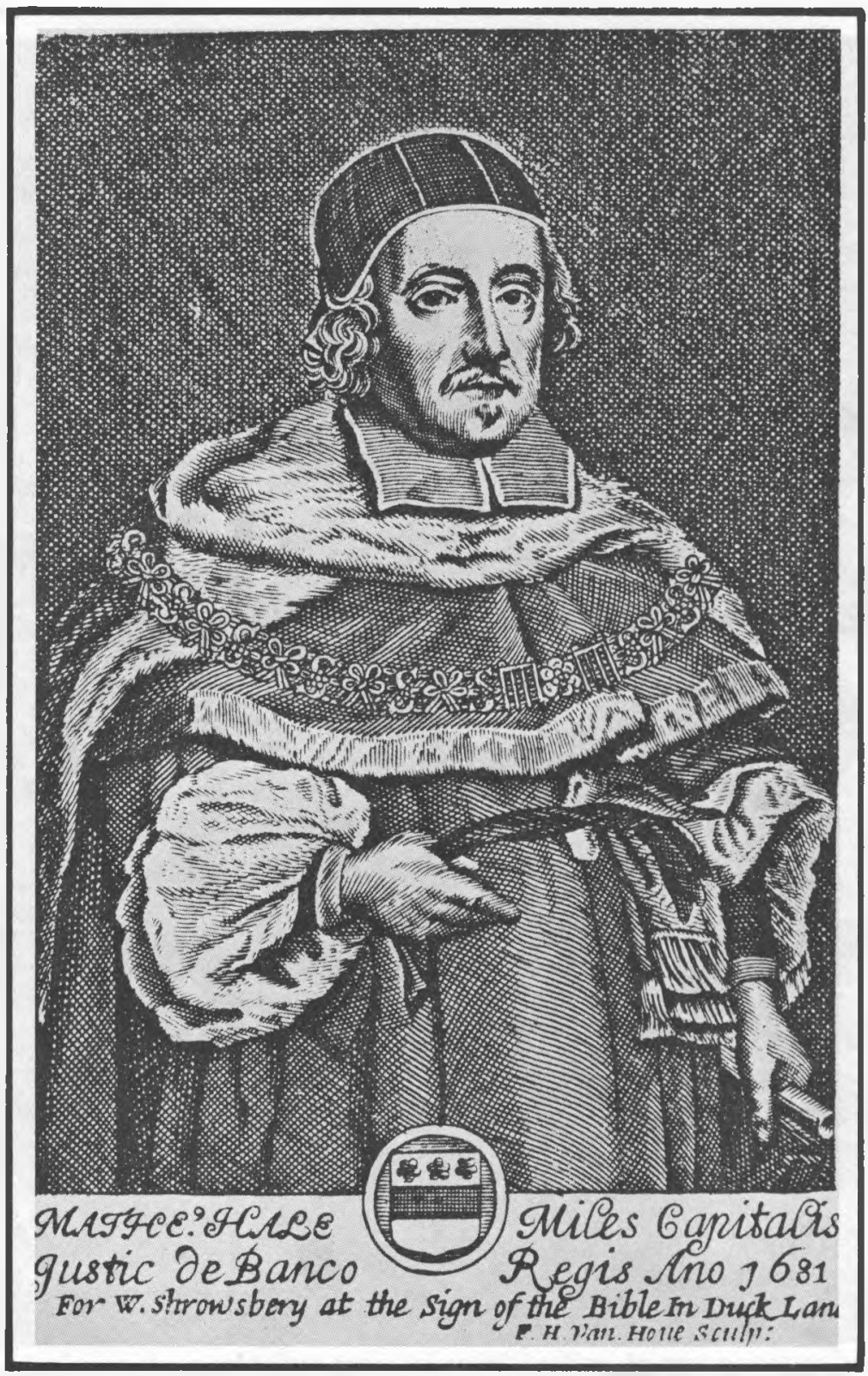

A portrait of Chief Justice Matthew Hale (1609-1676), some of whose books on scientific, religious, or legal subjects were published by William Shrowsbury of Duck Lane. Note the reference to Shrowsbury under the portrait. From a copy of Hale's A Discourse of the Knowledge of God, and of Our Selves (1688) in The University of Iowa Libraries. 


\section{DIFFICILES NUG E: O R, \\ OBSER VATIONS Touching the \\ TORRICELLIAN Experiment, \\ A N D}

The various Solutions of the fame, efpecially touching the Weight and Elafticity of the Air. Bys'm: Hale.

The second EDITION, with fome occafienal Additions.

\section{$\angle O N D O N$,}

Printed by W. Godbid, for William Shrowsbury, at the Sign of the Bible in Duck-lane, M. DC. LXXV.

Title page of a scientific work by Sir Matthew Hale published by William Shrowsbury at the sign of the Bible, Duck Lane, in 1675. From a copy in the History of Hydraulics Collection, The University of Iowa Libraries. It was at Shrowsbury's shop that Samuel Pepys "did baiser" the proprietor's wife "in las tenebras." 


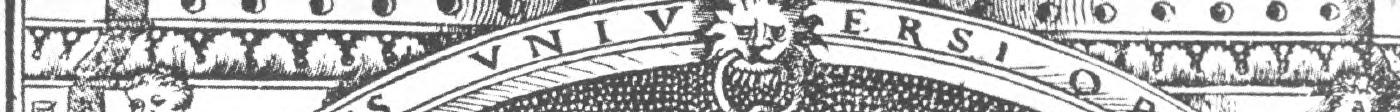

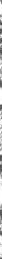

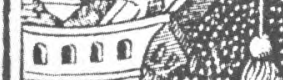
迹宙:

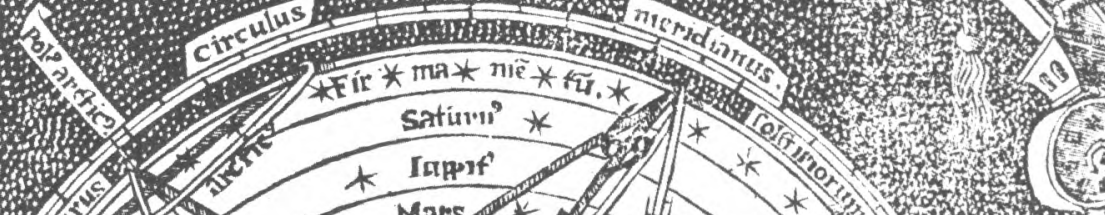
(1)

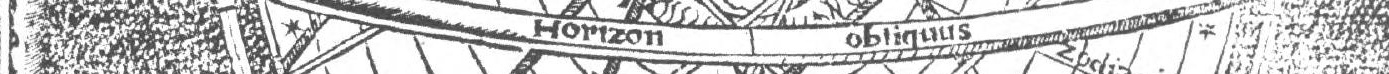
( (2) (3) (3) (x)

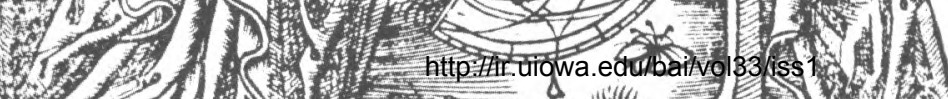
- 1

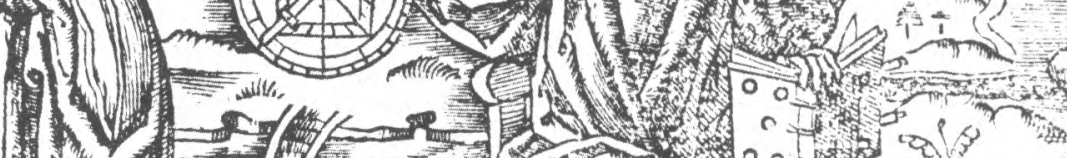

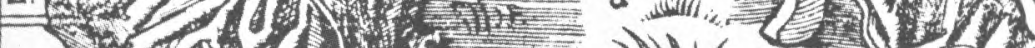

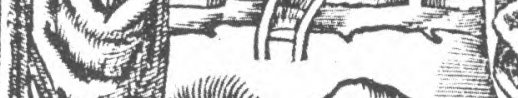

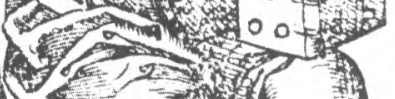

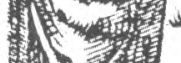
(n)
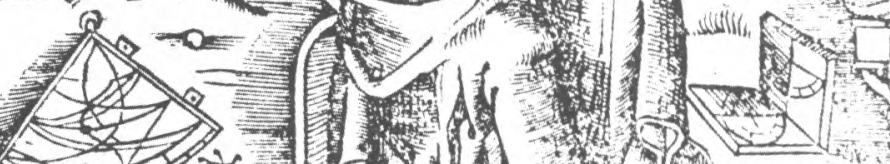